Historic, archived document

Do not assume content reflects current scientific knowledge, policies, or practices. 


\section{THE FLOWERING CRABS}

(Malus species and varieties)

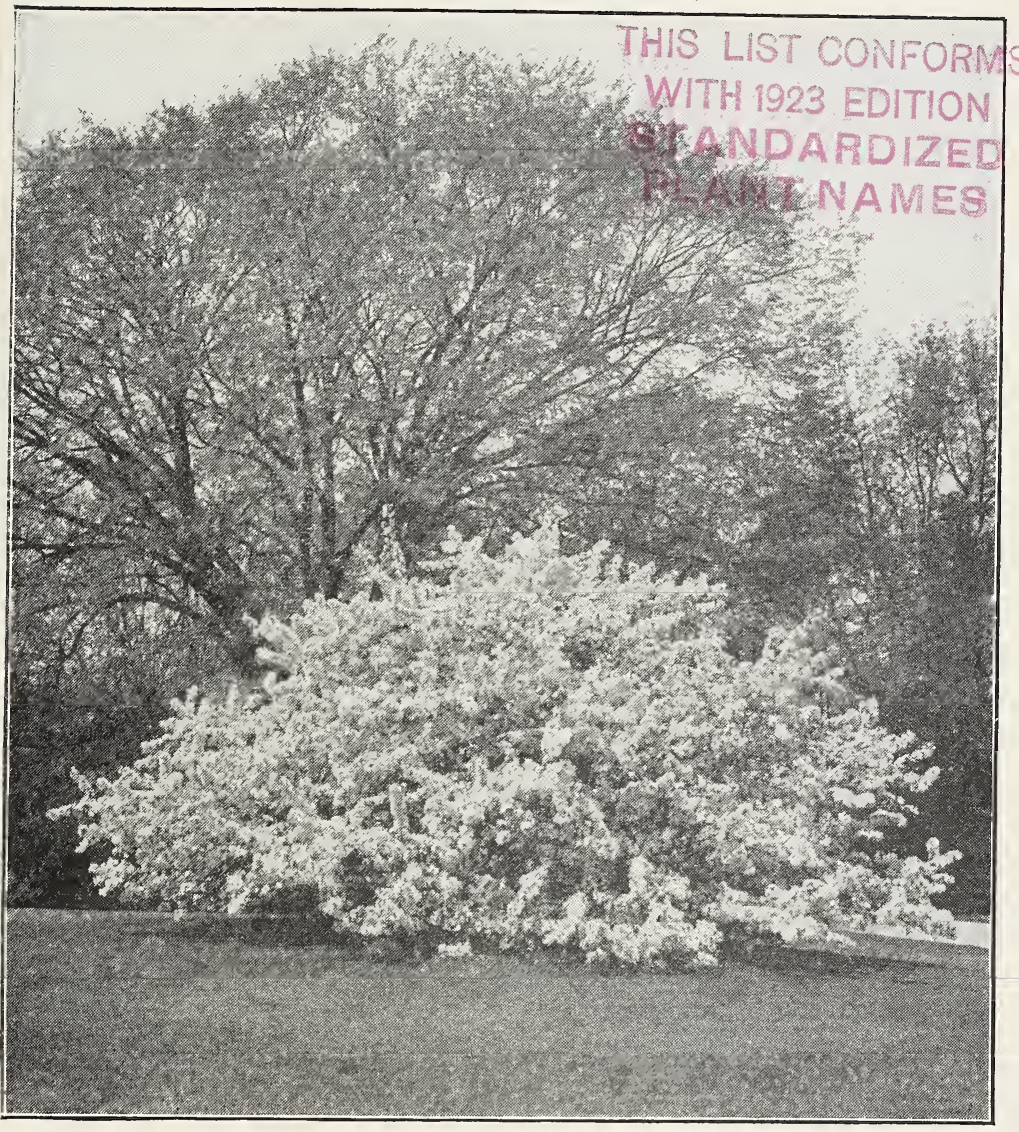

MALUS FLORIBUNDA, Japanese Flowering Crab.

The Flowering Crabs have few rivals among gorgeous Spring flowering trees and shrubs. At the Arnold Arboretum one of the important events of the year is the blooming of the Crabs, followed by the showy fruit.

They are of easy culture, and whether planted singly or in masses, give remarkable and quick results. Not only are the Flowering Crabs beautiful on the lawn, but they are used to the greatest advantage on a large scale in woodland and other mass plantings, as are Dogwoods and Hawthorns. No group of plants have greater value for enlivening open forest parks and the country roadside. They present striking effects when planted on parking strips of boulevards and wide city streets.

As soon as the ground can be worked is an ideal time for planting. Give rich soil and mulch heavily. Use all the water the soil will take in planting.

Description of species and varieties made up from Arnold Arboretum Bulletins. 


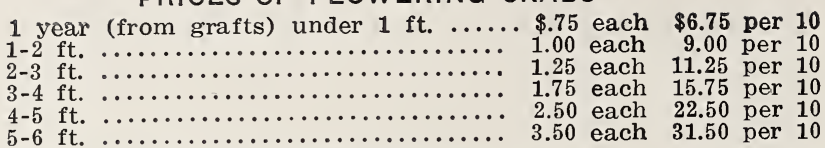

MALUS AUGUSTIFOLIA, Southern Crab.

Late blooming American species, bright pink and very fragrant. Size, 1 year from grafts.

MALUS ARNOLDIANA, Arnold Crab.

One of the most beautiful varieties, originating at the Arnold Arboretum. Very large rose-colored flowers, turning to white. Size, 1 year from grafts.

MALUS ATROSANGUINEA, Carmine Crab.

Much like floribunda, but with brilliant carmine flowers. Sizes, 1 year from grafts, 2-3 ft., 3-4 ft., and 4-5 ft.

MALUS BACCATA, Siberian Crab.

Tall, narrow tree, small white flowers and tiny orange or scarlet fruit. Size, 1 year from grafts.

MALUS BACCATA MANDSHURICA, Manchurian Crab.

From China and Japan; its large pure white flowers quite fragrant: dark crimson fruit hangs on long stems. Size, 1 year from grafts.

MALUS CORONARIA, Wild Sweet Crab.

White and pink flowers, delightfully fragrant. Native American species. Sizes, 1 year from grafts, 1-2 ft., 2-3 ft., and 3-4 ft.

MALUS FLORIBUNDA, Japanese Flowering Crab.

One of the handsomest, bright pink flower buds, white flowers. Small yellowish fruit, much liked by birds. Sizes, 1 year from grafts and $3-4 \mathrm{ft}$.

MALUS HALLIANA PARKMANI, Parkman Crab. Bright rose-red, double flowers hang on long slender stems. A favorite in Japanese gardens. Size, 1 year from grafts.

MALUS IOENSIS PLENA, Bechtel Crab.

Double pink flowers like small clustered roses. Sizes, 1 year from grafts, $18-24$ in., and 2-3 ft.

MALUS MICROMALUS, Midget Crab.

Pale pink flowers from tiny deep rose-colored buds; small yellow fruit. Pyramidal habit. Size, 1 year from grafts.

MALUS NIEDZWETZKYANA, Redvein Crab.

A Russian Turkestan species, remarkable for the red color of flowers, branches, leaves and fruit. Sizes, 1 year from grafts, 2-3 ft., 3-4 ft., 4-5 ft., and 5-6 ft.

MALUS PRUNIFOLIA, Pearleaf Crab.

Rare and perhaps the handsomest of the Asiatic Crabs, at least in fruit, which is $1 \frac{1}{2}$ in. long, very lustrus, bright red, or yellow with a red cheek. Sizes, 4-5 ft. and 5-6 ft.

MALUS PRUNIFOLIA RINKI (ringo), ChInese Apple.

Large white flowers, and red, yellow or green fruit, $1 \frac{1}{2}$ inches in diameter. Cultivated for its fruit in China. Size, 1 year from grafts.

MALUS ROBUSTA, Cherry Crab.

Very early. Large white fragrant flowers and a handsome tree. Dull red fruit, 1 inch in diameter. Sizes, 1 year from grafts, and $5-6 \mathrm{ft}$.

MALUS SARGENTI, Sargent Crab.

Very dwarf spreading Japanese variety. Pale straw-color flowers with bright yellow anthers. Scarlet fruit hanging till Spring. Size, 1 year from grafts.

MALUS SCHEIDECKERI, Scheidecker Crab.

Small tree of pyramidal habit, with small pink flowers in great profusion. Sizes, 1 year from grafts, and 3-4 ft.

MALUS SIEBOLDI (toringo), Torlngo Crab. Latest of the Asiatic Crabs to flower; bright red flower-buds and white flowers in greatest profusion. Large bright red, lustrous, persistent fruit. Size, 1 year from grafts.

MALUS SIEBOLDI CALOCARPA.

"One of the handsomest (crabs) in the Arboretum, both in Spring and Autumn." Large pink and white flowers, brilliant scarlet fruit, half-inch in diameter. Size, 1 vear from grafts.

MALUS SPECTABILIS, ChInese Flowering Crab.

Tall shrub or small tree, large pink semi-double flowers, mediumsize yellow fruit. Size, 1 year from grafts.

MALUS ZUMI, Zumi Crab.

Pink and white flowers, bright scarlet fruit. Sizes, 1 year from grafts, and $3-4 \mathrm{ft}$. 